\title{
DOES COMPOSTING OF BIODEGRADABLE MUNICIPAL SOLID WASTE ON THE LANDFILL BODY MAKE SENSE?
}

\author{
Dana Adamcová', Magdalena Vaverková \\ 1 Department of Applied and Landscape Ecology, Faculty of Agronomy, Mendel University in Brno, Zemědělská \\ Str. 1,61300 Brno, Czech Republic, e-mail: dana.adamcova@mendelu.cz, magda.vaverkova@uake.cz
}

Received: 2015.11.16

Accepted: 2015.12.09

Published: 2016.01.06

\begin{abstract}
In this study white mustard (Sinapis alba) plants were allowed to grow in earthen pots, treated with municipal solid waste compost (MSWC) to study the effect of MSWC on the plant biomass production. Twenty-one days from the establishment of the experiment sprouts and the number of growing plants occurring in the earthen pots were counted. Plants growing in the earthen pots with the compost samples exhibited an increasing plant biomass while no changes were observed in their appearance; retarded growth or necrotic changes were not recorded. The performed phytotoxicity tests show that the analyzed composts produced in the composting plant situated on the landfill surface achieved high percentages of the germinating capacity of white mustard (Sinapis alba) seeds and can be therefore used in the subsequent reclamation of the concerned landfill.
\end{abstract}

Keywords: waste, household waste recycling, phytotoxicity, Sinapis alba, landfill reclamation.

\section{INTRODUCTION}

Sanitary landfills, as a method of disposal, are standard practice in today's waste management. The large amounts of municipal solid waste (MSW) generated and the potential for landfills to be a future source of problems indicate that this approach may not be sustainable [Das et al. 2002]. MSW is largely made-up of kitchen and yard waste, and its composting has been adopted by many municipalities [Otten 2001]. Composting of MSW is seen as a method of diverting organic waste materials from landfills while creating a product, at relatively low-cost, that is suitable for agricultural purposes [Eriksen et al. 1999, Wolkowski 2003]. MSW composting has proved to be a safe and effective way to reduce MSW in large quantities and produce a stable humus-like material, beneficially reused as a soil amendment. As an alternate soil amendment, MSW compost is gaining high popularity [Zhao et al. 2012].

This trend may be attributed to economic and environmental factors, such as municipal landfill capacity; costs associated with landfilling and transportation of materials; adoption of legislation to protect the environment; decreasing the use of commercial fertilizers; increasing the capacity for household waste recycling and improved quality of compost products [Otten 2001, He et al. 1992, Hansen et al. 2006, Zhang et al. 2006].

A significant interest towards the use of municipal solid waste compost (MSWC) application for agricultural purposes is getting popular due to the dearth of availability of conventionally used raw materials for compost preparation [Gigliotti et al. 1996, Hargreaves et al. 2008, Karak et al. 2013, Karak et al. 2014, Lakhdar et al. 2010]. On the other hand, the growing interest on MSWC application is associated with an element of concern, which is the presence of considerable amount of heavy metals. MSWC often contains potentially toxic metals that can cause phytotoxicity, soil contamination, and accumulation in plant and animal products [Karak et al. 2013, Topcuoğlu 2005, Zhao, Duo 2015, Carbonell et al. 2011, Jordao et al. 2006, Kabata-Pendias, Pendias 2001, Khan 2001, Laborda et al. 2007, Shanker 2005] 
Studies have shown several beneficial effects of MSWC towards better crop management, as it may be considered as a source of different major nutrients and micronutrients to plants [Hargreaves et al. 2008, Hicklenton et al. 2001, Zhou et al. 2013]. Therefore, the advantages or disadvantages of using MSWC as fertilizer and soil amendment should be evaluated with the possible environmental and toxicological impacts together, due to the presence of potentially toxic elements such as heavy metals [Karak et al. 2013].

At present, legislative measures in different countries prohibit the application of MSWC to arable soils and as such, these organic materials have been widely utilized in land reclamation activities. As a matter of fact, the presence of considerable residual concentrations of heavy metals (including $\mathrm{Cd}, \mathrm{Cr}, \mathrm{Cu}, \mathrm{Ni}, \mathrm{Pb}$ and $\mathrm{Zn}$ ) in these organic materials is the main problem associated with their application to soil. These heavy metals can be leached through the soil profile, transported in drainage waters, and may pollute groundwater, or they can accumulate in the upper soil layer and can be toxic to plants and soil microbial biomass [Businelli et al. 2009].

The overall objectives of the present study were: (1) to characterize and to evaluate MSWC produced on the landfill body, (2) to investigate the phytotoxicity of the compost and finally, (3) to evaluate the possibility of using this compost to landfill reclamation. The eco-toxicological impact of the compost was evaluated by plant growth tests with white mustard (Sinapis alba).

\section{MATERIAL AND METHODS}

\section{Site description}

The Kuchyňky landfill is situated in a triangular space delimited by main roads connecting the villages of Zdounky, Nětčice and Troubky-Zdislavice at a distance of ca. $1800 \mathrm{~m}$ NNW of the church in Zdounky, $750 \mathrm{~m} \mathrm{NNW}$ of the built-up area limits in Zdounky and $450 \mathrm{~m}$ SW of the boundary line of Nětčice (Figure 1). In terms of maintenance, the landfill is classified in the S-category - other waste, sub-category S-OO3. The designed area of the landfill is $70700 \mathrm{~m}^{2}$ in five stages with a total volume of $907000 \mathrm{~m}^{3}$, i.e. ca. $100000010^{3} \mathrm{~kg}$ of waste. Up to now, Stage I of $19200 \mathrm{~m}^{2}$ has been constructed together with parts of Stage II $\left(5500 \mathrm{~m}^{2}\right)$ and Stage III $\left(7500 \mathrm{~m}^{3}\right)$. Planned service life of the facility is up to year 2018 .

The facility receives waste (category of other waste) from a catchments area with the population of ca. 75000 residents. The annually deposited amount of waste is ca. 40000 $10^{3} \mathrm{~kg}$ of which $50 \%$ are from the communal sphere. The approved landfill sector for waste of sub-category S-OO1 has not been opened yet. The sector will be intended for the disposal of waste (category of other waste) with the low content of organic biologically degradable substances. A sector of the landfill will be intended largely for the disposal of asbestos-containing wastes, gypsum-based waste, stabilized waste, waste with the high sulphur

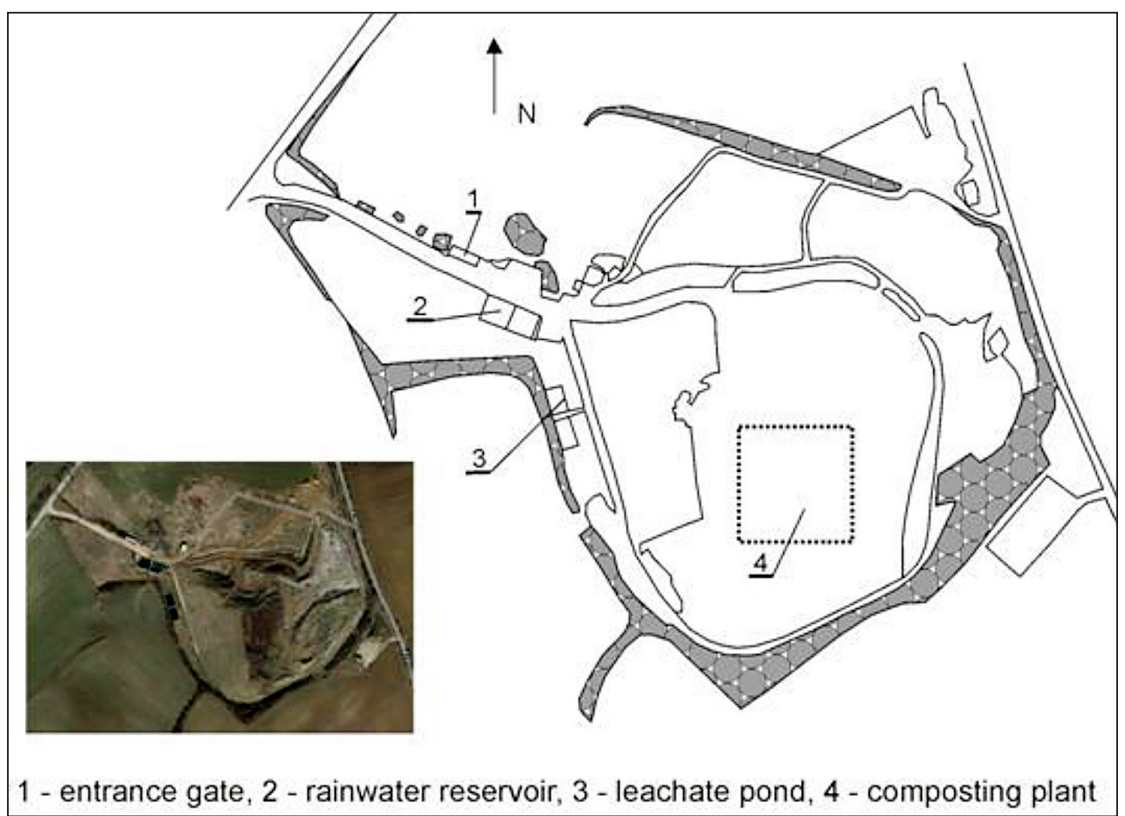

Figure 1. Scheme and aerial photograph (insert) of the landfill site 
content and waste with the increased content of metals. Waste with the substantial content of organic biologically degradable substances must not be stored in that sector.

\section{Composting at the landfill body}

The composting plot is located on the landfill body surface. Composted materials are biologically degradable wastes (BDW) that are transported from the surrounding towns and villages. They mainly consist of greenery from the maintenance of towns and villages and also of biologically degradable communal waste collected from households in the refuse collection area. The estimated capacity of wastes received by this composting plant is $2.00010^{3}$ $\mathrm{kg} / \mathrm{year}$. The facility is designed for the collection, purchase and exploitation of waste waste management code R3 pursuant to Annex 3 of the Waste Law as amended.

The composting plant is situated within the II b stage plot of the landfill (Figure 2). On this site, waste disposal had been terminated; the plot was subjected to ground shaping, covered with earth and recycled material, and compacted. The size of the composting plant is $20 \times 35 \mathrm{~m}$. According to conditions (amount of compostable waste), 6-8 compost back fills were established of triangular profile sized $30 \times 1.5 \mathrm{~m}$ and a height of $0.8 \mathrm{~m}$ (Figure 3).

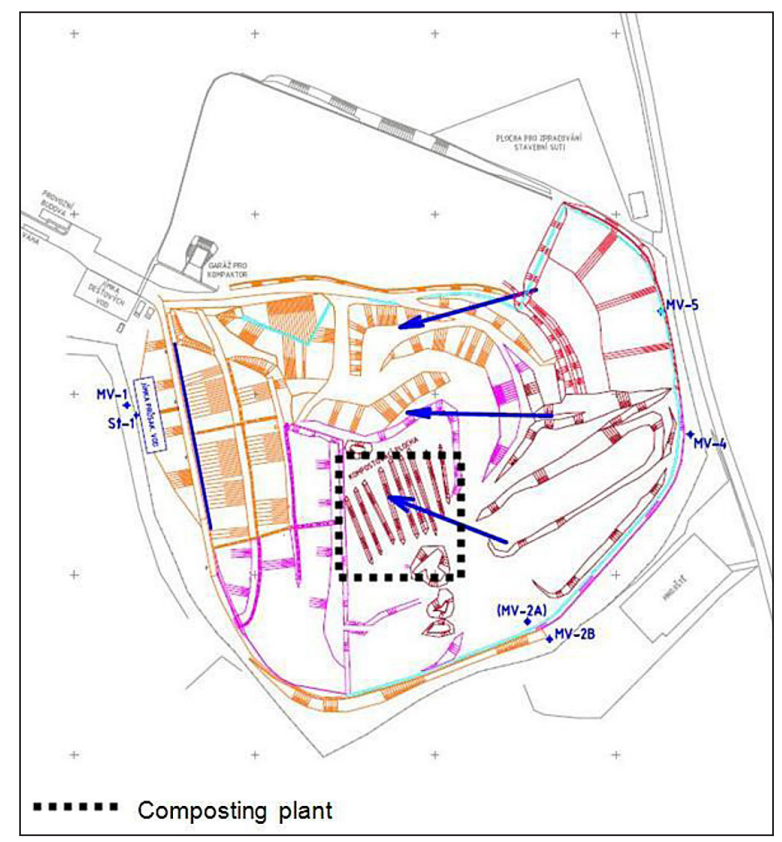

Figure 2. Location of composting plant

\section{Phytotoxicity test}

Phytotoxicity of compost (sieved and not sieved) (Figure 4) was investigated by means of a set of biological tests using white mustard (Sinapis $a l b a)$ as the test plant. The possible toxicological effect of compost was assessed according to CSN EN 13432 on the growth of dicotyledonous plants. Reference soil was composed of commercial potting soil and silica sand (8:2) and thoroughly mixed. The medium was commercial potting soil for germination and plant growth and silica sand (8:2), enriched with compost $(25 \%, 50 \% \mathrm{w} / \mathrm{w})$. Soil without compost was used as a control. Each earthen pots of diameter $11 \mathrm{~cm}$ and height $10 \mathrm{~cm}$ were loosely filled with $200 \mathrm{~g}$ of medium, then 100 seeds were scattered on to the surface, covered with a thin layer of silica sand and the earthen pots were covered with a glass plate (to avoid evaporation). Glass plates were removed when the germinated plants touched them. Plants were grown under controlled conditions for 21 days. Humidity at level of $70-100 \%$ of water absorption capacity, low light intensity, and the laboratory temperature were maintained to be constant. Values obtained from two simultaneously conducted experiments were averaged and presented (germination capacity). Photographs were taken to document the establishment of the trial. During the experiment, evaporated water was regularly added as needed.

\section{Plant material}

Seeds used as plant material for testing were commercial seeds of white mustard (Sinapis $a l b a$ ). Seeds were surface-sterilized by soaking for $2 \mathrm{~min}$ in a commercial sodium hypochlorite (2\%) solution wit a few drops of Tween-20. Then they were rinsed twice in sterile distilled water.

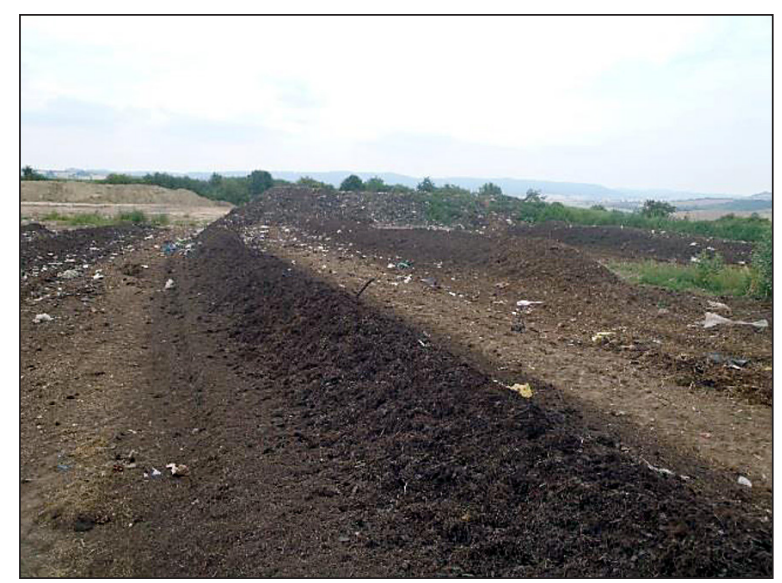

Figure 3. Composting piles 


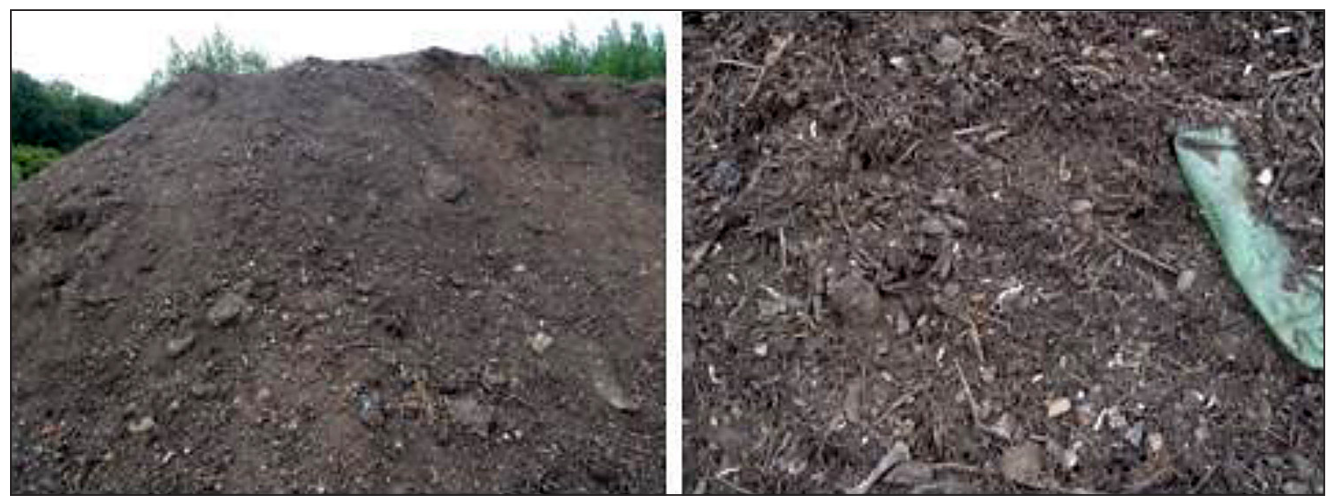

Figure 4. Samples of sieved and not sieved compost

\section{RESULTS}

Compost samples were taken from the composting plant in the Kuchyňky landfill for chemical analyses, which were conducted in the testing laboratory of Laboratoř MORAVA s.r.o. authorized by the Czech Accreditation Institute.

Results from the analyses of compost samples - mixed compost sample (the samples were collected from different compost piles by crap sampling method) and compost - are presented in Table 1 and Table 2 .

The compost produced in the given composting plant was sampled. The samples were designated as A-samples (August 2014): A1 - mixed compost sample, A2 - compost, and B-samples (September 2014): B1 - mixed compost sample, B2 - compost. The samples were collected into sterilized plastic containers. Then they were designated and brought to the laboratory at Mendel University in Brno, Department of Applied and Landscape Ecology where they were kept at a temperature of $-4{ }^{\circ} \mathrm{C}$ until the Phytotoxicity test.

After 14 and 21 days, germinating capacity of seeds and plant growth were assessed for A samples (A1 and A2) and B-samples (B1 and $\mathrm{B} 2$ ). Germinating capacity was evaluated and the course of the experiment was documented photographically. Germinating capacity and growth of white mustard (Sinapis alba) are shown in Figure 5. The resulting counts of individual A1 and A2 samples were recorded (Table 3). The same procedure was used also for samples B1 and B2 (Table 4).

The obtained data served for the calculation of values and evaluation of results. The numbers

Table 1. Average results of the analysis of mixed compost sample

\begin{tabular}{|c|c|c|l|c|}
\hline Parameter & Result & \multicolumn{1}{|c|}{ Unit } & \multicolumn{1}{|c|}{ Testing method identification } & Accr. \\
\hline $\mathrm{As}$ & 5.2 & $\mathrm{mg} / \mathrm{kg}$ DM & SOP 02 C (ČSN EN ISO 15586) & $\mathrm{A}^{*}$ \\
\hline $\mathrm{Cd}$ & 0.64 & $\mathrm{mg} / \mathrm{kg}$ DM & SOP 02 C (ČSN EN ISO 5961) & $\mathrm{A}$ \\
\hline $\mathrm{Cr}$ & 35.3 & $\mathrm{mg} / \mathrm{kg}$ DM & SOP 23 C (ČSN EN 1233) & $\mathrm{A}$ \\
\hline $\mathrm{Cu}$ & 40.4 & $\mathrm{mg} / \mathrm{kg}$ DM & SOP 23 C (ČSN ISO 8288) & $\mathrm{A}$ \\
\hline $\mathrm{Hg}$ & 0.116 & $\mathrm{mg} / \mathrm{kg}$ DM & SOP 03 (ČSN 465735, ČSN721227) & $\mathrm{A}$ \\
\hline $\mathrm{Ni}$ & 21.8 & $\mathrm{mg} / \mathrm{kg}$ DM & SOP 23 C (ČSN ISO 8288) & $\mathrm{A}$ \\
\hline $\mathrm{Pb}$ & 29.5 & $\mathrm{mg} / \mathrm{kg}$ DM & SOP 23 C (ČSN ISO 8288) & $\mathrm{A}$ \\
\hline $\mathrm{Zn}$ & 174 & $\mathrm{mg} / \mathrm{kg}$ DM & SOP 23 C (ČSN ISO 8288) & $\mathrm{A}$ \\
\hline $\mathrm{Humidity}$ & 42.38 & $\%$ & SOP 32 C (ČSN EN 12879) & $\mathrm{A}$ \\
\hline $\mathrm{pH}$ & 8.39 & - & SOP 44 (JPP - ÚKZÚZ, Brno) & $\mathrm{A}$ \\
\hline $\mathrm{K}$ & 12.6 & $\mathrm{~g} / \mathrm{kg}$ DM & SOP 28 B (JPP - ÚKZÚZ, Brno) & $\mathrm{A}$ \\
\hline $\mathrm{P}$ & 2.77 & $\mathrm{~g} / \mathrm{kg} \mathrm{DM}$ & SOP 62 A (JPP - ÚKZÚZ, Brno) & $\mathrm{A}$ \\
\hline Combustibles matters & 20.5 & $\%$ in DM & SOP 32 (ČSN EN 12879) & $\mathrm{A}$ \\
\hline $\mathrm{N}_{\text {total }}$ & 1.18 & $\%$ in DM & SOP 61 A (JPP - ÚKZÚZ, Brno) & $\mathrm{A}$ \\
\hline $\mathrm{C:N}$ & 9 & - & SOP 85 (JPP - ÚKZÚZ, Brno) & $\mathrm{N}^{* *}$ \\
\hline
\end{tabular}

Mixed sample - taken from randomly selected places in the compost.

${ }^{*} \mathrm{~A}$ - accredited test, ${ }^{* *} \mathrm{~N}$ - non-accredited test, DM - dry mass. 
Table 2. Average results of the analysis of compost sample

\begin{tabular}{|c|c|c|c|c|}
\hline Parameter & Result & Unit & Testing method identification & Accr \\
\hline As & 5.45 & $\mathrm{mg} / \mathrm{kg} \mathrm{DM}$ & SOP 02 C (ČSN EN ISO 15586) & $A^{*}$ \\
\hline $\mathrm{Cd}$ & 0.67 & $\mathrm{mg} / \mathrm{kg} \mathrm{DM}$ & SOP 02 C (ČSN EN ISO 5961) & $A$ \\
\hline $\mathrm{Cr}$ & 34.3 & $\mathrm{mg} / \mathrm{kg} \mathrm{DM}$ & SOP 23 C (ČSN EN 1233) & A \\
\hline $\mathrm{Cu}$ & 40.3 & $\mathrm{mg} / \mathrm{kg} \mathrm{DM}$ & SOP 23 C (ČSN ISO 8288) & $A$ \\
\hline $\mathrm{Hg}$ & 0.114 & $\mathrm{mg} / \mathrm{kg} \mathrm{DM}$ & SOP 03 (ČSN 465735, ČSN721227) & A \\
\hline $\mathrm{Ni}$ & 22.2 & $\mathrm{mg} / \mathrm{kg} \mathrm{DM}$ & SOP 23 C (ČSN ISO 8288) & A \\
\hline $\mathrm{Pb}$ & 28.9 & $\mathrm{mg} / \mathrm{kg} \mathrm{DM}$ & SOP 23 C (ČSN ISO 8288) & A \\
\hline $\mathrm{Zn}$ & 174 & $\mathrm{mg} / \mathrm{kg} \mathrm{DM}$ & SOP 23 C (ČSN ISO 8288) & A \\
\hline Humidity & 42.38 & $\%$ & SOP 32 C (ČSN EN 12879) & A \\
\hline $\mathrm{pH}$ & 8.37 & - & SOP 44 (JPP - ÚKZÚZ, Brno) & A \\
\hline $\mathrm{K}$ & 15.5 & g/kg DM & SOP 28 B (JPP - ÚKZÚZ, Brno) & A \\
\hline $\mathrm{P}$ & 6.82 & $\mathrm{~g} / \mathrm{kg} \mathrm{DM}$ & SOP 62 A (JPP - ÚKZÚZ, Brno) & A \\
\hline Combustibles matters & 28.5 & $\%$ in DM & SOP 32 (ČSN EN 12879) & A \\
\hline $\mathrm{N}_{\text {total }}$ & 1.17 & $\%$ in DM & SOP 61 A (JPP - ÚKZÚZ, Brno) & A \\
\hline C:N & 12 & - & SOP 85 (JPP - ÚKZÚZ, Brno) & $\mathrm{N}^{* *}$ \\
\hline
\end{tabular}

* A - accredited test, ${ }^{* *} \mathrm{~N}-$ non-accredited test, DM - dry mass.

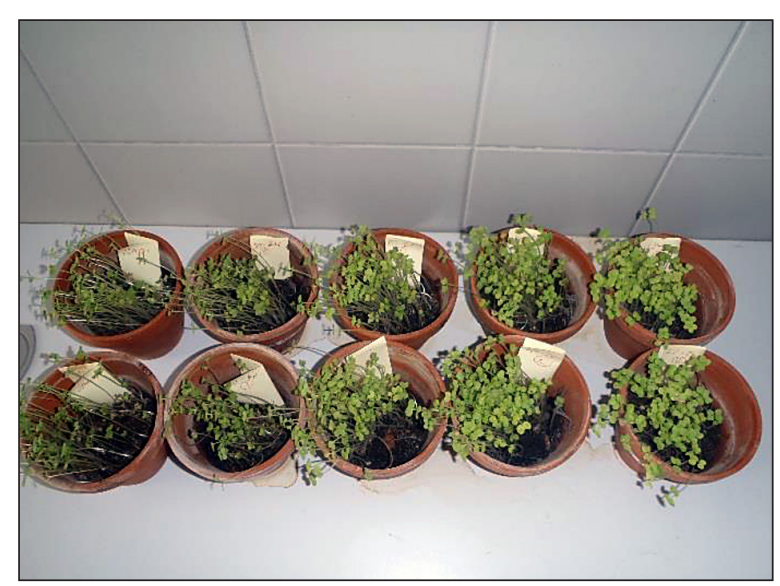

Figure 5. Illustration of the germinating capacity of Sinapis alba seeds

Table 3. Results of the germinating capacity of Sinapis alba (samples A)

\begin{tabular}{|c|c|c|}
\hline Samples - August 2014 & \multicolumn{2}{|c|}{ Summary - germination test } \\
\hline $25 \%$ & 14 days & 21 days \\
\hline Blank 1 & 87 & 91 \\
\hline Blank 2 & 80 & 84 \\
\hline A2 25a & 77 & 79 \\
\hline A2 25b & 92 & 94 \\
\hline A1 25a & 72 & 83 \\
\hline A1 25b & 79 & 78 \\
\hline $50 \%$ & 14 days & 21 days \\
\hline Blank 1 & 87 & 91 \\
\hline Blank 2 & 80 & 84 \\
\hline A2 50a & 77 & 78 \\
\hline A2 50b & 79 & 81 \\
\hline A1 50a & 60 & 64 \\
\hline A1 50b & 73 & 76 \\
\hline
\end{tabular}

of sprouts (number of growing plants) were compared for all mixing ratios of compost samples ( $\mathrm{A}$ and $\mathrm{B}$ ) and on compost from the blind experiment. Germinating capacity was calculated as a percentage of corresponding values obtained from the compost in the blind experiment.

Tables 5 and 6 show average values calculated from experimental results and include also percentages of germinating capacity for the individual analyzed samples.

The highest germinating capacity (99\%) of white mustard (Sinapis alba) seeds was recorded after 21 days in sample A2 with $25 \%$ of compost, and the highest germinating capacity (91\%) after

Table 4. Results of the germinating capacity of Sinapis alba (B)

\begin{tabular}{|c|c|c|}
\hline Samples - September 2014 & \multicolumn{2}{|c|}{ Summary -germination test } \\
\hline $25 \%$ & 14 days & 21 days \\
\hline Blank 1 & 64 & 80 \\
\hline Blank 2 & 60 & 92 \\
\hline B2 25a & 57 & 84 \\
\hline B2 25b & 49 & 88 \\
\hline B1 25a & 53 & 82 \\
\hline B1 25b & 48 & 82 \\
\hline $50 \%$ & 14 days & 21 days \\
\hline Blank 1 & 64 & 80 \\
\hline Blank 2 & 60 & 92 \\
\hline B2 50a & 56 & 88 \\
\hline B2 50b & 60 & 86 \\
\hline B1 50a & 54 & 87 \\
\hline B1 50b & 58 & 84 \\
\hline
\end{tabular}


Table 5. Average values and percentages of the germinating capacity of Sinapis alba (samples A)

\begin{tabular}{|c|c|c|c|c|}
\hline Samples - August 2014 - Mean & \multicolumn{2}{|c|}{ Summary - germination test } & \multicolumn{2}{c|}{ Percent number of seeds germinated } \\
\hline $25 \%$ & 14 days & 21 days & 14 days & 21 days \\
\hline Blank & 84 & 88 & - & - \\
\hline A2 25 & 85 & 87 & 101 & 99 \\
\hline A1 25 & 76 & 81 & 90 & 21 days \\
\hline $50 \%$ & 14 days & 21 days & 14 days & - \\
\hline Blank & 84 & 88 & - & 91 \\
\hline A2 50 & 78 & 80 & 93 & 80 \\
\hline A1 50 & 67 & 70 & 80 & \\
\hline
\end{tabular}

Table 6. Average values and percentages of the germinating capacity of Sinapis alba (samples B)

\begin{tabular}{|c|c|c|c|c|}
\hline Samples - September 2014 - Mean & \multicolumn{2}{|c|}{ Summary - germination test } & \multicolumn{2}{c|}{ \% number of seeds germinated } \\
\hline $25 \%$ & 14 days & 21 days & 14 days & 21 days \\
\hline Blank & 62 & 86 & - & - \\
\hline B2 25 & 53 & 86 & 85 & 95 \\
\hline B1 25 & 51 & 82 & 81 & 21 days \\
\hline $50 \%$ & 14 days & 21 days & 14 days & - \\
\hline Blank & 62 & 86 & - & 101 \\
\hline B2 50 & 58 & 87 & 94 & 100 \\
\hline
\end{tabular}

21 days was recorded in sample A2 with $50 \%$ of compost.

The highest germinating capacity $(100 \%)$ of white mustard (Sinapis alba) seeds was recorded after 21 days in sample B2 with $25 \%$ of compost, and the highest germinating capacity (101\%) after 21 days was recorded in sample B2 with 50\% of compost.

Figure 6 presents percentages of the germinating capacity of white mustard (Sinapis alba) seeds ( $25 \%, 50 \%$ of compost A1 and A2) after 14 days from the beginning of the experiment and after 21 days (end of the experiment).

The highest germinating capacity of seeds was achieved in sample A2 25 both after 14 days
(101\%) and after 21 days (99\%). The second and third highest values of seed germinating capacity were nearly identical for sample A1 25 and sample A2 25 with the germinating capacity of seeds ranging from $90-93 \%$. Sample A1 50 exhibited the lowest germinating capacity of seeds both after 14 days (80\%) and after 21 days $(80 \%)$ from the establishment of the trial. Pursuant to the standard, values below $90 \%$ are considered slightly toxic.

Figure 7 presents percentages of the germinating capacity of white mustard (Sinapis alba) seeds $(25 \%$ and $50 \%$ of compost in B1 and B2) after 14 days from the beginning of the experiment and after 21 days (end of the experiment).

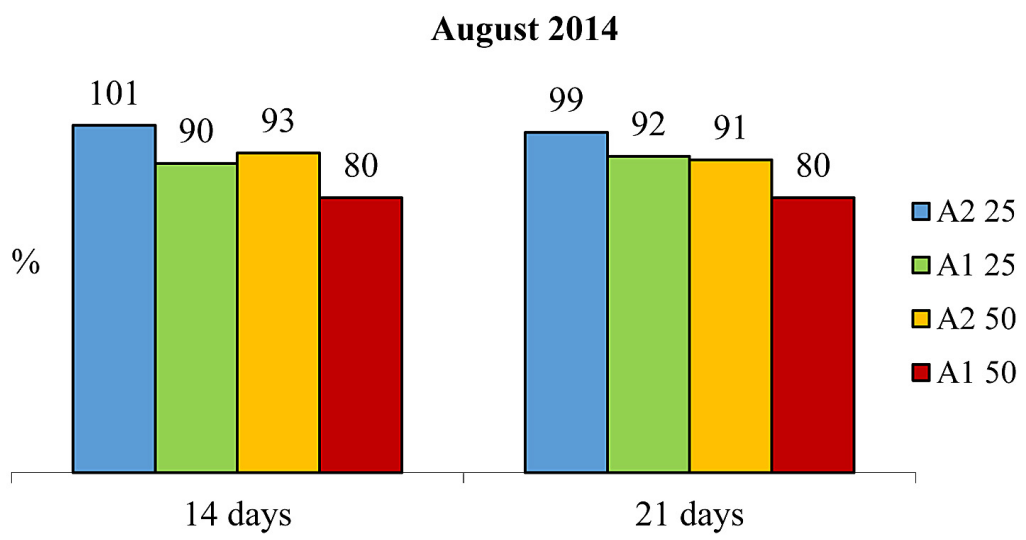

Figure 6. Comparison of the germinating capacity of seeds in A compost samples 


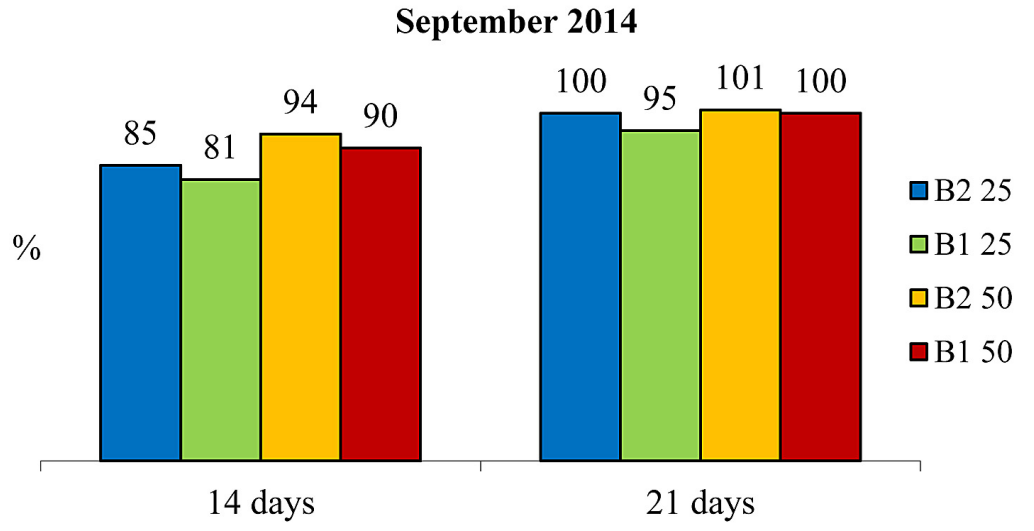

Figure 7. Comparison of the germinating capacity of seeds in B compost samples

The highest germinating capacity of seeds was achieved in sample B2 50 both after 14 days (94\%) and after 21 days (101\%). The second highest value of seed germinating capacity was found in sample B1 both after 14 days $(90 \%)$ and after 21 days (100\%). Sample B2 25 exhibited the third highest values (14 days - 85\%, 21 days $100 \%$ ). Sample B1 25 exhibited the lowest germinating capacity of seeds both after 14 days (81\%) and after 21 days (95\%) from the establishment of the trial.

\section{CONCLUSIONS}

The two performed phytotoxicity tests show that the analyzed composts produced in the composting plant situated on the landfill surface achieved high percentages of the germinating capacity of white mustard (Sinapis alba) seeds and can be therefore used in the subsequent reclamation of the concerned landfill.

Standard CSN EN 13432 states that the analyzed compost does not exhibit phytotoxicity if the indicator of germinated seeds is not lower than $90 \%$, as compared with plants growing in the control sample. Sample A1 50 exhibited the seed germinating capacity of $80 \%$ in both cases. Values below $90 \%$ are considered slightly phytotoxic according to the standard. Values below $90 \%$ were further found in samples B2 25 (85\%) and B1 25 (81\%) after 14 days from the beginning of the experiment. However, after 21 days (at the end of the experiment), both samples exhibited values higher than 90\% (B2 $25-100 \%$, B1 $25-95 \%)$. Thus, the samples were not toxic for the plants at the end of the test.

Advantages of composting on the landfill body consist in the full exploitation of landfill space, in landfill security and in the used technology. Biologically degradable waste is not stored in the landfill, which is the main objective of European regulations concerning the management of biologically degradable waste, but its material is exploited (landfill reclamation). This method brings benefits of both economic (transportation costs, building of composting plant, technical support) and environmental character (emissions during transport and handling, fuel consumption, dustiness, noise etc.).

\section{Acknowledgements}

This study was supported by the firm DEPOZ of the city of Zdounky. We would like to express our great appreciation to the management of the landfill Kuchyňky. Namely, we are very grateful to Ing. Ivan Mohler and his colleagues for their assistance and their willingness to provide their time so generously.

\section{REFERENCES}

1. Das K.C., Smith M.C., Gattie D.K., Hale Boothe D.D. 2002. Stability and quality of municipal solid waste compost from a landfill aerobic bioreduction process. Adv. Environ. Res. 6 (4), 401-409.

2. Otten L. 2001. Wet-dry composting of organic municipal solid waste: current status in Canada. Can. J. Civil. Eng. 28 (Suppl. 1), 124-130.

3. Eriksen G., Coale F., Bollero G. 1999. Soil nitrogen dynamics and maize production in municipal solid waste amended soil. Agron. J. 91 (6), 1009-1016.

4. Wolkowski R.P. 2003. Nitrogen management considerations for landspreading municipal solid waste compost. J. Environ. Qual. 32 (5), 1844-1850.

5. Zhao S., Liu X., Duo L. 2012. Physical and chemical characterization of municipal solid waste com- 
post in different particle size fractions. Pol. J. Environ. Stud. 21 (2), 509-515.

6. He X., Traina S., Logan T. 1992. Chemical properties of municipal solid waste compost. J. Environ. Qual. 21 (3), 318-329.

7. Hansen T., Bhander G., Christensen T., Bruun S., Jensen L. 2006. Life cycle modeling of environmental impacts of application of processed organic municipal solid waste on agricultural land (EASEWASTE). Waste Manag. Res. 24 (2), 153-166.

8. Zhang M., Heaney D., Henriquez B., Solberg E., Bittner E. 2006. A four-year study on influence of biosolids/MSW cocompost application in less productive soils in Alberta: nutrient dynamics. Compost Sci. Util. 14 (1), 68-80.

9. Karak T., Paul R.K., Sonar I., Sanyal S., Ahmed K.Z., Boruah R.K., Das D.K., Dutta A.K. 2014. Chromium in soil and tea (Camellia sinensis L.) infusion: Does soil amendment with municipal solid waste compost make sense? Food Res. Int. 64, 114-124.

10. Gigliotti G., Businelli D., Giusquiani P.L. 1996. Trace metals uptake and distribution in corn plants grown on a 6-year urban waste compost amended soil. Agric. Ecosyst. Environ. 58 (2-3), 199-206.

11. Hargreaves J.C., Adl M.S., Warman P.R. 2008. A review of the use of composted municipal solid waste in agriculture. Agric. Ecosyst. Environ. 123 (1-3), 1-14.

12. Lakhdar A., Iannelli M.A., Debez A., Massacci A., Jedidi N., Abdelly C. 2010. Effect of municipal solid waste compost and sewage sludge use on wheat (Triticum aestivum): Growth, heavy metal accumulation and antioxidant activity. Journal of the Science of Food and Agriculture, 90, 965-971.

13. Karak T., Bhattacharyya P., Paul R.K., Das T., Saha S.K. 2013. Evaluation of composts from agricultural wastes with fish pond sediment as bulking agent to improve compost quality. Clean-Soil, Air, Water. 41 (7), 711-723.

14. Topcuoğlu B. 2005. Effects of repeated applications of sewage sludge and MSW compost on the bioavailability of heavy metals in greenhouse soil. Pol. J. Environ. Stud. 14 (2), 217-222.
15. Zhao S., Duo L. 2015. Bioaccumulation of Cadium, Copper, Zinc, and Nickel by Weed Species from Municipal Solid Waste Compost. Pol. J. Environ. Stud. 24 (1), 413-417.

16. Carbonell G., De Imperial R.M., Torrijos M., Delgado M., Rodriguez J.A. 2011. Effects of municipal solid waste compost and mineral fertilizer amendments on soil properties and heavy metals distribution in maize plants (Zea mays L.). Chemosphere. 85 (10), 1614-1623.

17. Jordao C.P., Nascentes C.C., Cecon P.R., Fontes R.L.F., Pereira J.L. 2006. Heavy metal availability in soil amended with composted urban solid wastes. Environ. Monit. Assess. 112 (1-3), 309-326.

18. Kabata-Pendias A., Pendias H. 2001. Trace elements in soils and plants. CRC Press, Boca Raton, FL, USA.

19. Khan A.G. 2001. Relationships between chromium biomagnification ratio, accumulation factor, and mycorrhizae in plants growing on tannery effluentpolluted soil. Environ. Int. 26 (5-6), 417-423.

20. Laborda F., Górriz M.P., Bolea E., Castillo J.R. 2007. Mobilization and speciation of chromium in compost: A methodological approach. Sci. Total Environ. 373 (1), 383-390.

21. Shanker C., Cervantes A.K., Loza-Tavera H., Avudainayagam S. 2005. Chromium toxicity in plants. Environ. Int. 31 (5), 739-753.

22. Hicklenton P.R., Rodd V., Warman P.R. 2001. The effectiveness and consistency of source-separated municipal solid waste and bark composts as components of container growing media. Sci. Hortic. 91 (3-4), 365-379.

23. Zhou Y., Ning X., Liao X., Lin M., Liu J., Wang J. 2013. Characterization and environmental risk assessment of heavy metals found in fly ashes from waste filter bags obtained from a Chinese steel plant. Ecotoxicol. Environ. Saf. 95, 130-136.

24. Businelli D., Massaccesi L., Said-Pullicino D., Gigliotti G. 2009. Long-term distribution, mobility and plant availability of compost-derived heavy metals in a landfill covering soil. Sci. Total Environ. 407 (4), 1426-1435. 